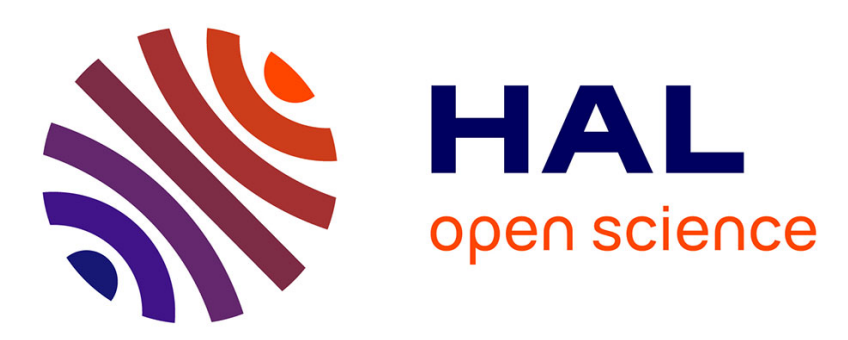

\title{
Effect of temperature and time on properties of Spark Plasma Sintered NiCuZn: Co ferrite
}

\author{
Karim Zehani, Frederic Mazaleyrat, Vincent Loyau, Eric Labouré
}

\section{To cite this version:}

Karim Zehani, Frederic Mazaleyrat, Vincent Loyau, Eric Labouré. Effect of temperature and time on properties of Spark Plasma Sintered NiCuZn: Co ferrite. Journal of Applied Physics, 2011, 109, pp.07A504. 10.1063/1.3561444 . hal-00608882

\section{HAL Id: hal-00608882 \\ https://hal.science/hal-00608882}

Submitted on 15 Jul 2011

HAL is a multi-disciplinary open access archive for the deposit and dissemination of scientific research documents, whether they are published or not. The documents may come from teaching and research institutions in France or abroad, or from public or private research centers.
L'archive ouverte pluridisciplinaire $\mathbf{H A L}$, est destinée au dépôt et à la diffusion de documents scientifiques de niveau recherche, publiés ou non, émanant des établissements d'enseignement et de recherche français ou étrangers, des laboratoires publics ou privés. 


\title{
Effect of temperature and time on properties of Spark Plasma Sintered NiCuZn: Co ferrite
}

\author{
K. Zehani, ${ }^{1, \text { a) }}$ F. Mazaleyrat, ${ }^{1}$ V. Loyau, ${ }^{1}$ and E. Labouré ${ }^{2}$ \\ ${ }^{1)}$ SATIE, Ecole Normale Superieure de Cachan, CNRS, Universud \\ 61, avenue du President Wilson, F94230 Cachan, France \\ ${ }^{2)}$ LGEP, SUPELEC Univ. Paris-Sud, CNRS \\ 11 rue Joliot Curie, Plateau de Moulon, F91192 Gif sur Yvette, France
}

(Dated: 2 November 2010)

Spark Plasma Sintering is a powerfal method to produce fine grain dense ferrite at low temperature. However, the process, usually conducted in neutral atmosphere in a carbon die, yields carbon surface deposition and reduction of $\mathrm{Fe}^{3+}$ into $\mathrm{Fe}^{2+}$. It's shown that subsequent annealing in air can remove carbon and, under some conditions, produce complete oxidation of $\mathrm{Fe}^{2+}$ ions. Regular values of the resistivity and permittivity (resp. $1 \mathrm{M} \Omega \mathrm{m}, 13 \varepsilon_{0}$ ) are recovered for most samples annealed not higher than $750^{\circ} \mathrm{C}$. Relatively high value of the permeability (up to 240) and high merit factor $\left(\mu_{s} \times f_{r}>5 \mathrm{GHz}\right)$ have been achieved.

PACS numbers: 75.50.Gg, 75.75.Cd, 81.20.Ev, 81.40.Rs

Keywords: Spark Plasma Sintering, Spinel ferrite, Grain size, Complex real permittivity, Complex initial permeability

\section{INTRODUCTION:}

The latest research in power electronics have focused on the miniaturization of electronic boards in particular by reducing the size of active components. Today, there is a tremendous demand of passive components reduction, particularly magnetic ones usually based on spinel ferrite. These ferrites attracted a lot of attention because of their magnetic behavior and their applications in power electronics devices for from the radio frequency $(300 \mathrm{kHz}$ to $3 \mathrm{MHz})$ to microwave $(3 \mathrm{MHz}$ to $20 \mathrm{GHz})$. The NiZn ferrite possesses a relative high initial permeability up to several hundred $\mathrm{MHz}$, and a high resistivity, but the conventional sintering temperature is too high for co-sintering with silver or copper conductors (Sintering temperature at $1250^{\circ} \mathrm{C}$ ). However, if copper is substituted in a proportion of $0.1-0.2$, the conventional sintering temperature is decreased down to $950^{\circ} \mathrm{C}^{1}$. This study will focus on studying the effect of temperature and sintering time using the Spark Plasma Sintering process ${ }^{2}$ on structural, dielectric and magnetic properties of $\mathrm{NiCuZn}$ ferrite doped with cobalt.

\section{EXPERIMENTAL:}

Powders of basic oxides $\mathrm{Fe}_{2} \mathrm{O}_{3}, \mathrm{NiO}, \mathrm{CuO}$ and $\mathrm{ZnO}$ and $\mathrm{Co}_{2} \mathrm{O}_{3}$ were used for the preparation of $\mathrm{NiCuZn}$ ferrite using the standard technique of ceramics: jar mixture of precursor oxides, adding $\mathrm{Co}_{2} \mathrm{O}_{3}$ - in order to decreased the magneto-crystalline anisotropy constant -, calcination at $760^{\circ} \mathrm{C}$ for two hours and grinding by attrition for $30 \mathrm{~min}$. The molar ratio was adjusted to achieve the following composition: $\mathrm{Ni}_{0.195} \mathrm{Cu}_{0.2} \mathrm{Zn}_{0.599} \mathrm{Co}_{0.006} \mathrm{Fe}_{2} \mathrm{O}_{4}$.
This composition was checked after sintering by SEMEDS which confirms this composition within the accuracy of the method (Co was not detected). The sintering was carried out at different temperatures to determine the optimum properties at low sintering temperature. To investigate the structural and dielectric properties different pellets $\varnothing 8$ have been produced by SPS between 650 and $800^{\circ} \mathrm{C}$ in steps of $50^{\circ} \mathrm{C}$ under a uni-axial pressure of $50 \mathrm{MPa}$, in neutral atmosphere (Argon) with a heating rate of $160^{\circ} \mathrm{Cmin}^{-1}$ followed by a plateau of 0 to 15 min and cooling $160^{\circ} \mathrm{Cmin}^{-1}$. After sintering, the two faces of each sample were polished to remove graphite pollution from the pistons. For each sample, a second was made under the same conditions but with additional treatment at $500^{\circ} \mathrm{C}$ under air in order to burn residual carbon an reoxyde the surface. The crystal structure of the different sintered samples was studied by Xray diffraction using a PANalytical X'Pert PRO MPD diffractometer, with cobalt source. The area swept in this study is between $20^{\circ}$ and $80^{\circ}$ in steps of $0.001^{\circ}$. The relative density was calculated as the ratio of the experimental density measured by Archimedes method and the theoretical density deduced from lattice parameter. To determine the crystallite size, the spectra were refined by the Rietveld method using the software Maud ${ }^{4}$. The electrical resistivity was measured using a multimeter by the four points method. The dielectric permittivity and complex initial permeability as a function of frequency (between $100 \mathrm{kHz}$ and $500 \mathrm{MHz}$ ) have been determined by impedance spectroscopy (HP $4195 \mathrm{~B}$ ). To make the measurements of dielectric properties before and after annealing, we have deposited a gold layer about $100 \mathrm{~nm}$ by Sputtring. The permeability measurements were performed in coaxial cell, with ring samples $\left(\varnothing_{\text {ext }}=8 \mathrm{~mm}\right.$, $\varnothing_{\text {int }}=4 \mathrm{~mm}$ and $\mathrm{h}=3 \mathrm{~mm}$ ).

a)Electronic mail: karim.zehani@satie.ens-cachan.fr 
TABLE I. Initial permeability, relaxation frequency and merit factor of SPS ferrite toroids

\begin{tabular}{|c|c|c|c|c|c|c|c|c|c|c|c|c|}
\hline \multirow[b]{2}{*}{ Time } & \multicolumn{3}{|c|}{ Sintering at $650^{\circ} \mathrm{C}$} & \multicolumn{3}{|c|}{ Sintering at $700^{\circ} \mathrm{C}$} & \multicolumn{3}{|c|}{ Sintering at $750^{\circ} \mathrm{C}$} & \multicolumn{3}{|c|}{ Sintering at $800^{\circ} \mathrm{C}$} \\
\hline & $5 \mathrm{~min}$ & $10 \mathrm{~min}$ & $15 \min$ & $5 \mathrm{~min}$ & $10 \mathrm{~min}$ & $15 \min$ & $5 \mathrm{~min}$ & $10 \mathrm{~min}$ & $15 \mathrm{~min}$ & $5 \mathrm{~min}$ & $10 \mathrm{~min}$ & $15 \mathrm{~min}$ \\
\hline$\mu_{i}$ & 17,3 & 17.4 & 17.4 & 34 & 39 & 52 & 126 & 156 & 178 & 152 & 213 & 242 \\
\hline$f_{r}(\mathrm{MHz})$ & 169 & 169 & 170 & 131 & 115 & 89 & 37 & 32 & 27 & 33 & 24 & 22 \\
\hline$\mu_{i}^{\prime} \times f_{r}(\mathrm{GHz})$ & 2.92 & 2.94 & 2.96 & 4.45 & 4.48 & 4.62 & 4.66 & 4.99 & 4.80 & 5.02 & 5.11 & 5.32 \\
\hline
\end{tabular}

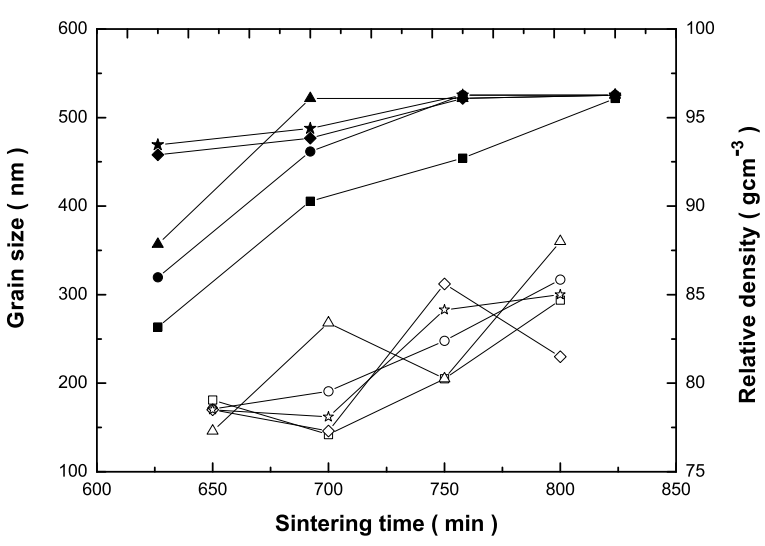

FIG. 1. Grain size and Relative density as a function of temperature and time of sintering: Square $(0 \mathrm{~min})$, Circle (1 min), Up Triangle (5 min), Diamond (10 min) and Star (15 min).

\section{RESULTS AND DISCUSSION:}

\section{A. Structural properties:}

X-ray diffraction patterns taken from the powder after calcination shows all peaks characteristic of the spinel phase and no trace of parasitic phase or basic oxides. Refinement of the spectra using an inverse spinel type ferrite structure confirms this conclusion and yields a grain size of $100 \mathrm{~nm}$. For sintered samples, no difference is visible -the lattice parameter is always $841.7 \mathrm{pm}$ - except the crystallite size (Fig.1) which increases with sintering temperature. It is noticeable that the sintering time has little influence on this parameter. In contrast the relative density strongly depends on annealing step duration (see in set Fig.1). The strongest density (95\%) can be achieved even at $700^{\circ} \mathrm{C}$ if the temperature is maintained at least $5 \mathrm{~min}$.

\section{B. Dielectric properties:}

The electrical resistivity and complex permittivity were measured before and after burning in air to clarify the effect of carbon on ferrite. Figure 2 shows the resistivity versus sintering time for different sintering temperatures before and after burn. The large increase of re-

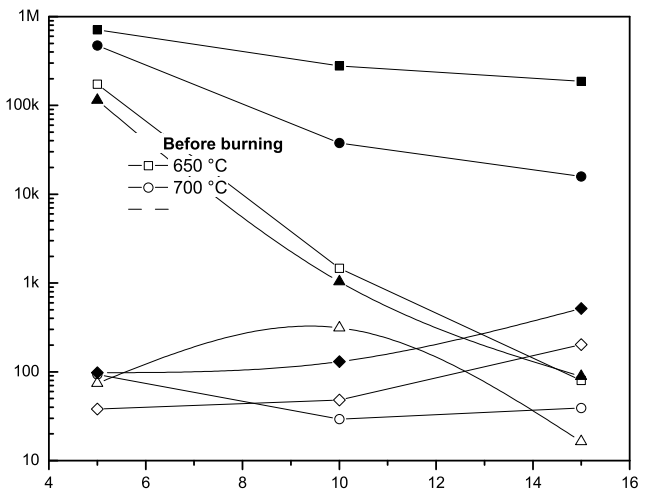

FIG. 2. Electric resistivity as a function of sintering time for different temperatures before and after burning

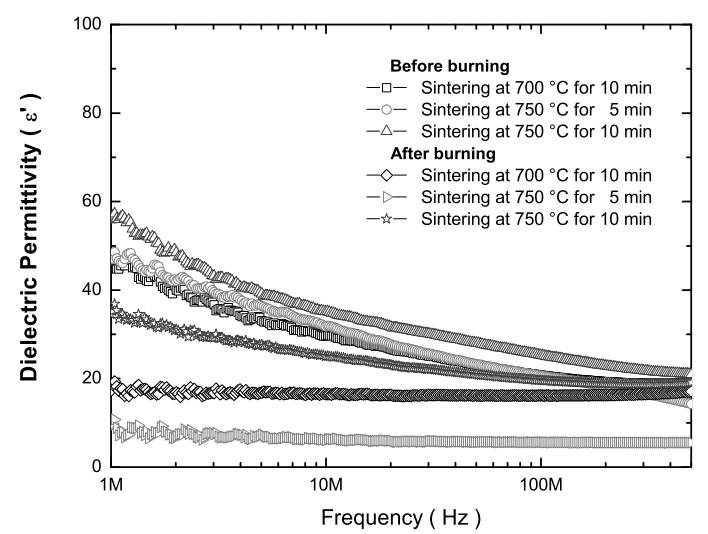

FIG. 3. Complex Permittivity as a function of frequency of sintering at 700 (top box) and $750^{\circ} \mathrm{C}$ (bottom box) before and after burning.

sistivity after burn may be explained by 2 phenomenons. First, SPS in a graphite die produces carbon evaporation and deposition at the surface of the sample, that short circuits the ferrite. This carbon layer is visible on XRD spectrum when recorded on as-sintered samples. Burn under air easily burns the surface deposited carbon. Secondly, the evaporated carbon can react with ferrite and after this treatment, the resistivity recovers the 
high value expected for NiZn ferrites, except for sample sintered at $800^{\circ} \mathrm{C}$ which are probably reduced in the bulk and cannot be reoxidised because the porosity is closed. To confirm the reduction of $\mathrm{Fe}^{3+}$ in to $\mathrm{Fe}^{2+}$ we investigated the dielectric properties of these ferrite in a frequency range between $1 \mathrm{MHz}$ and $500 \mathrm{MHz}$ at room temperature. Figure 3 shows the different spectra of complex permittivity for different plateau length and temperatures before and after burning $\left(500^{\circ} \mathrm{C}\right)$. For samples sintered at $\left(700^{\circ} \mathrm{C}\right)$ and burnt, the dielectric permittivity is constant - in agreement with literature - and the decrease as a function of frequency is no longer observed. This confirms the burn of carbon and re-oxidization of the surface. By opposition samples sintered at $750^{\circ} \mathrm{C}$ for 10 and $15 \mathrm{~min}$ still show after burning the decrease in $\varepsilon^{\prime}(\mathrm{f})$ probably because the porosity is closed (the relative density is larger than $96 \%$ ) so $F e^{2+}$ can't be oxidized back into $\mathrm{Fe}^{3+}$ in the bulk. The high permittivity at low frequency has been observed in CCTO and BTO ferroelectrics $^{5-13}$. The Internal Barrier Layer Capacitor (IBLC) effect is related to the micro-structure, composed of (semi)conducting grains separated by insulating grain boundaries. The effective relative permittivity given by $\varepsilon_{e f f}=\varepsilon_{g b} D / t$ depending on the grains size (D) and the average thickness of grain boundary (t).

\section{Complex initial permeability:}

Table 1 shows the values of initial permeability, relaxation frequency and merit factor for different samples sintered at $650,700,750$ and $800^{\circ} \mathrm{C}$. There is either an increase of complex permeability according to the sintering temperature and sintering duration. This increase is due to grain growth and porosity reduction ${ }^{14,15}$. Compared to the permeability values obtained by A. Lucas ${ }^{16}$ for the same types of ferrites sintered at $935^{\circ} \mathrm{C}$ for $2 \mathrm{~h}$ (conventional sintering), we note that the initial permeability is much lower, between 20 and 250, compared to 560 for conventional method. This is due to a much smaller grain size and probably to the single domain structure of the particles. The complex permeabilty spectra depicted in fig. 3 are showing the typical Snoek features as the real parts converges at high frequency. It is remarked that all of them exhibits a marked resonance in the real part characteristic of materials having a good homogeneity in terms of grain size and composition.

Tables 1 shows that the real part of the initial permeability is roughly proportional to the relaxation frequency $f_{r}$, which confirms Snoek's law ${ }^{17}$. Although the permeability is lower than that of conventionally sintered materials, the merit factor $\mu_{i} \times f_{r}$ is finally very close (up to 5.32 compared to $5.8 \mathrm{GHz}$ ).

In conclusion, this study has shown that SPS is very efficient for NiCuZn ferrite processing. These dense and well crystallized samples exhibits very fine grain size. The dielectric and magnetic properties can be controlled by sintering temperature and time, keeping a high value

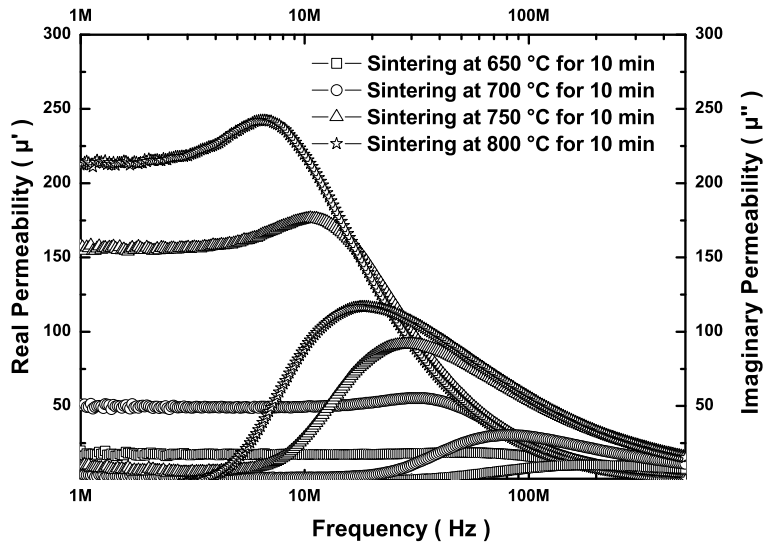

FIG. 4. Real and imaginary parts of the permeability for selected samples

of the merit factor. Samples annealed at $750^{\circ} \mathrm{C}$ for 5 min shows a good compromise in term of permeability, relaxation frequency $\left(f_{r}\right)$ and resistivity when submitted to re-oxidation treatment. Higher permeability can be obtained but only at the price of larger dielectric loss. Hence, SPS should be used for the fabrication of $\mathrm{NiCuZn}$ ferrite based integrated magnetic component using LTCC process.

${ }^{1} \mathrm{~J}$. Ageron, Thesis of INPG, Ferrites Ni-Cu-Zn low temperature sintering components for HF-VHF integrated, 1999.

${ }^{2}$ M. Tokita, J. Soc. Powder Tech. Jpn., Vol(30) 1993, 790-804.

${ }^{3}$ J. Smit, H. P. J. Wijin, Ferrites, in: Philips Technical Library, Eindhovan, Netherlands, 1959, pp. 221-245.

${ }^{4}$ H. M. Rietvel, J. Appl. Crystallogr., Vol(2), 1969, 65.

${ }^{5}$ W. Q. Ni, X.H. Zheng and J. C. Yu.J. Mater. Sci., Vol. V42(3), 1037-1041, 2007

${ }^{6}$ V. Brize, G. Gruener, J. Wolfman, K. Fatyeyeva, M. Tabellout, M. Gervais and F. Gervais.Mater. Sci and Eng. B, Vol 129(1-3), 135-138, 2006.

${ }^{7}$ T. T. Fang and H, K. Shiau. J. Am. Ceram. Soc., Vol. 87(11), 2072-2079, 2004.

${ }^{8}$ Y. Yan, L. Jin, L. Feng and G. Cao. Mater. Sci. and Eng. B, Vol. 130(1-3), 146-150 2006.

${ }^{9}$ B. Shri Prakash and K. Varma. J. Solid State Chem., Vol. 180(6), 1918-1927, 2007.

${ }^{10}$ C. C. Homes, T. Vogt, S. M. Shapiro, S. Wakimoto, M. Subramanian and A. P. Ramirez. Phys. Rev. B, Vol. 67(9), 092106, 2003.

${ }^{11}$ S. Y. Chung, S. Y. Choi, T. Yamamoto, Y. Ikuhara and S. J. L. Kang. Appl. Phys. Lett., Vol. 88(9), 091917, 2006.

${ }^{12}$ U-C. Chung, C. Elissalde, S. Mornet, M. Maglione and C. Estourns. Appl. Phys. Lett., Vol. 94, 072903, 2009

${ }^{13}$ S. Guillemet-Fritsch, Z. Valdez-Nava, C. Tenailleau, T. Lebey, B. Durand and J-Y. Adv. Mater, Vol. 20,2008,551-555.

${ }^{14}$ A.A. Sattar, H.M. El-Sayed, K.M. El-Shokrofy, M.M. ElShokrofy, M.M. El-Tabey, J. Appl. Sci Vol. 5(1), 2005, 162.

${ }^{15}$ A. Globus, P. Duplex, M. Guyot, IEEE Trans. Magn., Vol. 7, 1971, 617

${ }^{16}$ A. Lucas, PhD thesis, ENS Cachan, Study and development of broadband RF transformers, 2010.

${ }^{17}$ T. Nakamura, J. Appl. Phys., Vol 88(1), 2000, 348. 